\title{
Bioturbation/bioirrigation effect on thallium released from reservoir sediment by different organism types
}

\author{
Yi He, Bin Men *, Xiaofang Yang, Dongsheng Wang * \\ State Key Laboratory of Environmental Aquatic Chemistry, Research Centre for Eco-Environmental Science, Chinese Academy of Sciences, Beijing 100085, China
}

\section{H I G H L I G H T S}

- The total and particulate Tl concentrations had good correlations with turbidity.

- The bioturbation process suppressed the release of dissolved $\mathrm{Tl}$ from the sediment to water after 14 days.

- Loach has the most significant impact on Tl mobilization from sediment.

- Iron and manganese hydrous oxides may sorb or coprecipitate with $\mathrm{Tl}$.

- $\mathrm{Tl}(\mathrm{I})$ may be oxidated to be $\mathrm{Tl}(\mathrm{III})$ by planktonic bacteria.

\section{A R T I C L E I N F O}

\section{Article history:}

Received 9 April 2015

Received in revised form 12 June 2015

Accepted 19 June 2015

Available online 25 June 2015

Editor: F.M. Tack

\section{Keywords:}

Thallium

Bioturbation

Reservoir

Tubificid

Chironomid larvae

Loach

\section{G R A P H I C A L A B S T R A C T}

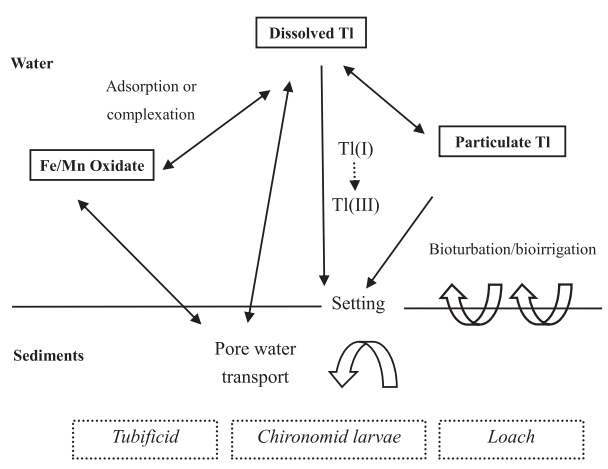

\section{A B S T R A C T}

Bioturbation can remobilize heavy metal in the sediments and may pose a risk for aquatic biota. The effects of bioturbation/bioirrigation by three different riverine organism types (Tubificid, Chironomid larvae, and Loach) on thallium release from contaminated sediment $(10.0 \pm 1.1 \mathrm{mg} \mathrm{Tl} / \mathrm{kg}$ sediment, dry wt.) were evaluated in this study. The bioturbation by the epibenthos clearly caused an increased turbidity in the overlying water, and the effect was in the order of Loach $>$ Chironomid larvae $>$ Tubificid. A significant release of $\mathrm{Tl}$ into the water column via the resuspended sediment particles was observed, especially for Loach. During the first few days, the leaching of dissolved $\mathrm{Tl}$ from sediment into water was fast, and the dissolved $\mathrm{Tl}$ under bioturbation/bioirrigation was much higher than the control group. However, after 14 days, the bioturbation/bioirrigation process seemed to suppress the release of $\mathrm{Tl}$ from the sediment particles to water, especially for sediment with Loach. This may partly be due to the sorption or coprecipitation of $\mathrm{Tl}$ simultaneous with the formation of iron and manganese hydrous oxides with increased $\mathrm{pH}$ values as a consequence of phytoplankton growth. Linear regression analysis confirmed that both the total and particulate $\mathrm{Tl}$ concentrations had good correlations with particulate Fe and Mn concentrations as well as turbidity in the overlying water. Additionally, planktonic bacteria may oxidize the $\mathrm{Tl}(\mathrm{I})$ to $\mathrm{Tl}(\mathrm{III})$, resulting in a reduced solubility of $\mathrm{Tl}$ by which $\mathrm{Tl}(\mathrm{OH})_{3}$ becomes the predominant form of $\mathrm{Tl}$.

(c) 2015 Elsevier B.V. All rights reserved.

\footnotetext{
* Corresponding authors.

E-mail addresses: binmen@rcees.ac.cn (B. Men), wgds@rcees.ac.cn (D. Wang).
}

\section{Introduction}

Thallium is a highly toxic element and is listed as a priority pollutant by the U.S. EPA (Liu et al., 2011; Mulkey and Oehme, 1993; Smith and Carson, 1977). It is a rare element in the natural environments usually with very low abundance (Peter and Viraraghavan, 2005). 
Thallium concentrations in the background soil of China ranged from $0.29-1.17 \mathrm{mg} / \mathrm{kg}$ (Qi et al., 1992); and $\mathrm{Tl}$ concentrations in Chinese typical background sediments were in the range of $0.30-$ $0.49 \mathrm{mg} / \mathrm{kg}$ (Zhao and Yan, 1994). However, Tl concentrations are elevated in the areas impacted by human activities and urban development (Lin et al., 2001; Lis et al., 2003). In China, an incidental Tl pollution (0.18-1.03 $\mathrm{Tl} \mu \mathrm{g} / \mathrm{L})$ from the wastewater discharge of a lead/zinc smelting plant on drinking water source of the northern branch of Pearl River was reported in 2010 (Agency, 2010), which further aroused public concerns on Tl pollution in China. Therefore, the study of the behaviors and the fate of $\mathrm{Tl}$ is significant and necessary.

Once introduced into the aquatic environment, $\mathrm{Tl}$ is redistributed throughout the water column, deposited and accumulated in sediments as a result of complex physical, chemical and biological processes (Larsson, 1985). Contaminants accumulate on organic (Sridhar et al., 2008), inorganic (Lin, 1997) sediment particles and their associated microorganism community (D'Souza et al., 2006). So sediments are an important medium to study the $\mathrm{Tl}$ behavior which may pose a risk for the ecological quality of surface waters (Duan et al., 2012). Some studies have shown that the disturbance by benthic organisms was an important process affecting secondary pollutants released, because of the behavior as buried hole, ingestion, breathing, movement and discharge. These behaviors changed the porosity, compaction, $\mathrm{pH}$ and redox potential distribution of sediments to affect the mutual exchange of pollutants among the sediment, sediment pore water and the overlying water (Banta and Andersen, 2003; Granberg et al., 2008; Hunting et al., 2013; Josefsson et al., 2010; Lagauzere et al., 2009; Nogaro et al., 2013; Thibodeaux and Bierman, 2003). Bioturbation brought the contaminated sediment particles to the interface of sediment and water, that these particle resuspension to provide a contaminated habitat for the benthic organisms lived in the surface sediment (Gang et al., 2006; Mermillod-Blondin et al., 2008; Rhoads, 1974; Schaller, 2014; Simpson et al., 1998; Tengberg et al., 2003; Thibodeaux and Bierman, 2003; Widdows et al., 1998). To date, however, it is not clear which are the effects of bioturbation/bioirrigation on Tl fluxes at the sediment-water interface.

Invertebrates and fish may mix sediment particles in a variety of ways. For example, Tubificid worms are important "conveyor-belt" feeders because dense populations can rapidly rework bottom deposits through selective ingestion of silt and clay (Dafoe et al., 2011). Jiang et al. (2010) compared bioturbation efficiency in Chironomus plumosus and Tanypus chinensis both of arthropoda; the authors demonstrated that the two organism types differ greatly in their feeding and burrowing activities, and certain Chironomid species may play important roles in driving nutrient cycling. Other researchers (Cardoso et al., 2008; Michaud et al., 2006) found that the gallery-diffusers (e.g., Hediste diversicolor) have greater effects than biodiffusers (e.g., bivalves) on the biochemical processes in marine sediment. Gallery-diffuser animals produce diffusion in the layer with very dense gallery systems and a bio-transport at the end of the burrows. The fauna burrows usually have significant effects on chemical fluxes and microbial activity. As H. diversicolor burrows deeper into the sediment, it irrigates a great volume of sediment, having a great influence on pore water chemistry, ammonium release and active bacteria. Additionally, these different activities of different organisms may have different effects on the heavy metal release, but there was little research on the effects before, especially for the riverine and reservoir conditions.

The aim of the present study was to investigate the effect of bioturbation/bioirrigation on the $\mathrm{Tl}$ remobilization from sediments to the water using $\mathrm{Tl}$ contaminated sediments in batch culture with three different types of organisms included Tubificid (Annelida), Chironomid larvae (arthropod) and Loach (vertebrate) as bioturbator. Furthermore, the accumulation of the $\mathrm{Tl}$ within the organisms was investigated.

\section{Materials and methods}

\subsection{Preparation of contaminated sediment and overlying water}

The sediment used as the original matrix was collected from uncontaminated surface sediment $(0-30 \mathrm{~cm})$ in the Ming Tombs Reservoir in north China in May 2013. Removed the gravel, plants and other impurities of the sediment and homogenized by mechanical mixing. The original component of the sediment was measured by a wavelength dispersive X-ray fluorescence spectrometer (WDXRF) (Rigaku ZSX Primus II) (Table 1). The water used as the overlying water was collected in the same place of the reservoir before collecting the sediment to avoid turbidity. The two were stored at $4{ }^{\circ} \mathrm{C}$ in the dark before use. Before being added to the experimental units, the sediment was spiked with $\mathrm{TINO}_{3}$ (AR, Sinopharm Chemical Reagent Co., Ltd. China) and the nominal Tl concentration being $10.0 \pm 1.1 \mathrm{mg} / \mathrm{kg}$ (dry weight) in the sediment. The artificially contaminated sediment was aged at room temperature for two months and stirred to allow uniform contamination.

\subsection{Organism}

Disturbed biologically selected Tubificid was collected from the pool in Fangshan southwest of Beijing, Chironomid larvae (C. plumosus larvae) were collected from the uncontaminated Yangliuqing River in the outer suburbs of Tianjin, and Loach were from the Miyun reservoir in the northeast of Beijing. The three organisms were cultured in clean water for no less than $48 \mathrm{~h}$ by cultivating them in laboratory conditions before use.

\subsection{Experimental design}

This experiment simulated the natural aquatic environment, carried out in an artificial climate chamber (RXZ intelligent, Ningbo Jiangnan Instrument Factory). The temperature was maintained at $23^{\circ} \mathrm{C}$, humidity remained $50 \%$ and the daily period of light at 16:24-hour throughout the entire experiment.

\subsubsection{Bioturbation/bioirrigation effects on $\mathrm{Tl}$ released from the sediment}

The basic structure of the experimental systems consisted of a glass beaker ( $2 \mathrm{~L}, \Phi 13 \times \mathrm{H} 19 \mathrm{~cm}$ ), lined with a high density polyethylene film. Sediment mesocosms were established by transferring $10 \mathrm{~cm}$ depth of spiked and free fauna sediment to each glass container. Then, $600 \mathrm{~mL}$ of filtered $(0.45 \mu \mathrm{m})$ reservoir water was carefully added to each glass container in order to avoid disturbance at the sediment surface. The glass containers were distributed in room temperature for a $24 \mathrm{~h}$ period of stabilization before introducing the organisms. After the $24 \mathrm{~h}$ stabilization equilibrium period, 2.0 gram organism $\left(7.5 \times 10^{5}\right.$ Tubificid per square meter, $9.4 \times 10^{4}$ Chironomid larvae per square meter, $1.5 \times 10^{2}$ Loach per square meter) was introduced into each glass container. The system with no organism added was used as a bioturbation/bioirrigation experiment blank. Four replicates were done for each condition. The complete experimental design consisted of 16 microcosms set up simultaneously. At the exposure time 1, 2, 3, 5, 7, 9, 14, 21 and 28 days, $10 \mathrm{~mL}$ of unfiltered water was sampled from each experiment beaker with a polypropylene syringe, then microwave digestion (MARS, China Everbest Machinery Industry Co., Ltd.) with aqua regia, stored at $4{ }^{\circ} \mathrm{C}$ and analyzed for total heavy metals within 3 days. $10 \mathrm{~mL}$ of filtered water was also sampled from each experiment beaker, filtered through a $0.45 \mu \mathrm{m}$ mixed cellulose ester membrane filter $(0.45 \mu \mathrm{m}, \mathrm{d}=25 \mathrm{~mm}$, Millipore, USA), then acidified with nitric acid and analyzed for dissolved heavy metals. The overlying water was added after each sampling and aeration for $5 \mathrm{~min}$. The $\mathrm{pH}$ and turbidity of the overlying water were measured for each unit during the exposure time of $1,2,3,5,7,9,11,14,17,21,24$, and 28 days. Thallium was determined by inductively coupled plasma mass spectrometry (ICP-MS) (7500a, Agilent Technologies Co. Ltd., America). 
Table 1

Principal geochemical characteristics of the natural sediment collected from the Ming Tombs Reservoir (north of China).

\begin{tabular}{|c|c|c|c|c|c|c|c|c|c|c|c|c|}
\hline Granulometry & \multicolumn{3}{|c|}{$>60 \mu \mathrm{m}$} & \multicolumn{2}{|c|}{$60-30 \mu \mathrm{m}$} & \multicolumn{2}{|c|}{$30-15 \mu \mathrm{m}$} & \multicolumn{2}{|c|}{$<15 \mu \mathrm{m}$} & $\mathrm{pH}$ & \multicolumn{2}{|c|}{ Loss by ignition } \\
\hline$\%$ & & & & & & & & & & & 7.9 & \\
\hline Major element & $\mathrm{C}$ & $\mathrm{N}$ & $\mathrm{P}$ & $\mathrm{S}$ & $\mathrm{Si}$ & $\mathrm{Al}$ & $\mathrm{Ca}$ & $\mathrm{Fe}$ & $\mathrm{Mg}$ & $\mathrm{K}$ & $\mathrm{Na}$ & $\mathrm{Ti}$ \\
\hline$\%$ & 4.70 & 0.72 & 0.08 & 0.07 & 22.60 & 8.03 & 3.55 & 3.18 & 1.80 & 2.08 & 1.04 & 0.42 \\
\hline
\end{tabular}

Iron and manganese were measured by inductively coupled plasma atomic emission spectrometry (ICP-AES) (Prodigy, Leeman Lab Inc., America).

\subsubsection{Bioaccumulation of $\mathrm{Tl}$}

To test if the bioaccumulation had effects on the Tl transfer process, the bioaccumulation of $\mathrm{Tl}$ by different organism types in the test sediment was also checked using 28-day laboratory bioassays. Various simulation devices in operation were as follows, each unit (plastic beaker, $1 \mathrm{~L}, \Phi 10 \times \mathrm{H} 13.8 \mathrm{~cm})$ consisted of contaminated sediment (1 cm depth), water column (300 mL) (2.1) and $1.0 \mathrm{~g}$ organisms. The sediment, overlying water and organism used were all the same with the three used in the bioturbation/bioirrigation experiment. Each experimental condition for four parallel samples was done. The complete experimental design consisted of 12 microcosms set up simultaneously. Replenish the overlying water every day to keep its quantity. The surviving organisms were sampled after 7, 14, 21, and 28 days. Biological samples were cleaned with Milli-Q water and freeze-dried (FD-1A, Beijing Bo Kang Experimental Medical Instrument Co., Ltd.) before microwave digestion with aqua regia. The $\mathrm{Tl}$ concentrations were analyzed on ICP-MS.

\subsection{Data analysis}

Analysis of variance (ANOVA) was used to explore the impact of bioturbation/bioirrigation by different type organisms on elemental mobilization with the exposure time. Statistical analyses were performed using SPSS Base 15.0 software. Pearson correlation coefficients were determined between $\mathrm{Tl}$ concentrations and relevant physicochemical parameters.

\section{Results}

\section{1. $\mathrm{pH}$ and turbidity}

From 0 to 11 days, $\mathrm{pH}$ values all increased for the four treatments, with highest values in the blank group (Fig. 1a). The $\mathrm{pH}$ values remained unchanged until the end of the experiment in the blank and Tubificid groups. In treatments with Chironomid, $\mathrm{pH}$ values increased to $8.6 \pm$ 0.2 at the 17 th day, then decreased to $8.0 \pm 0.1$ at the end of the experiment. After 11 days, the $\mathrm{pH}$ concentrations in the Loach group rapidly increased to $9.6 \pm 0.3$ at the 21 st day, then decreased to $9.0 \pm 0.2$ after 28 days.

Fig. 1b shows the turbidity concentration of the overlying water during the exposure time. Without bioturbation, turbidity remained at a very low level until the end of the experiment $(\leq 6.3 \pm 3.9$ NTU). With Tubificid, turbidity was slightly higher than for blank (1-28 d, Tubificid, $1.8 \pm 0.8-8.4 \pm 3.0 \mathrm{NTU}$ ). In the presence of Chironomid larvae, the turbidity rapidly decreased to $4.4 \pm 0.1$ NTU from 0 to 11 days, and then stabilized between $6.6 \pm 0.3$ and $23.3 \pm 3.1$ NTU. With Loach, turbidity rapidly decreased to $25.6 \pm 5.3$ NTU during the first 9 days, then increased sharply to $1286 \pm 221$ NTU after 28 days. The two treatments without organism and with Tubificid were not significantly different, but they were significantly different from the two treatments with Chironomid larvae and Loach.

\section{2. $\mathrm{Tl}$ in the overlying water}

During the early 5 days, the dissolved Tl concentrations (Fig. 2a) were in an upward trend and the metal concentrations of the biological group (5th d, Tubificid, $37.7 \pm 2.0 \mu \mathrm{g} / \mathrm{L}$; Chironomid larvae, $38.7 \pm$ $3.8 \mu \mathrm{g} / \mathrm{L}$; Loach, $42.7 \pm 3.8 \mu \mathrm{g} / \mathrm{L}$ ) were greater than that of the control group (blank, $33.4 \pm 1.2 \mu \mathrm{g} / \mathrm{L}$ ), indicating that bioturbation/bioirrigation accelerated the release of free $\mathrm{Tl}$ from sediment, in the order of Loach > Chironomid larvae $>$ Tubificid. From 5 to 9 days, the free Tl concentration gradually decreased and the concentration of bioturbation group was still greater than that of the control group. Finally, the free $\mathrm{Tl}$ concentrations in biological units (28th d, Tubificid, $15.9 \pm 0.7 \mu \mathrm{g} / \mathrm{L}$; Chironomid larvae, $18.1 \pm 1.4 \mu \mathrm{g} / \mathrm{L}$; Loach, $4.4 \pm 1.3 \mu \mathrm{g} / \mathrm{L}$ ) were all lower than that of the control team (blank, $20.1 \pm 0.9 \mu \mathrm{g} / \mathrm{L}$ ). During the first 14 days, the aqueous $\mathrm{Tl}$ concentration in the overlying water of the Loach group was the highest, but turned out to be the lowest at the end of the experiment

Particulate (Fig. 2b) and total (Fig. 2c) Tl concentrations in the overlying water had similar trends. During the first 14 days, the particulate concentrations of the Chironomid larvae and Loach groups basically remained stable, around $29.1 \pm 6.6-34.8 \pm 1.3$ and $35.4 \pm 5.9-$ $39.6 \pm 5.9 \mu \mathrm{g} / \mathrm{L}$, respectively. The total $\mathrm{Tl}$ concentration fluctuation ranges for the first 14 days were $53.9 \pm 9.0-75.2 \pm 3.5 \mu \mathrm{g} / \mathrm{L}$ for the Chironomid larvae group and $64.1 \pm 3.4-77.8 \pm 5.6 \mu \mathrm{g} / \mathrm{L}$ for the Loach group, respectively. Particulate and total $\mathrm{Tl}$ concentrations of the Tubificid group and the control group increased on the second day and then also remained relatively stable. During 2 to 14 days, the particulate $\mathrm{Tl}$

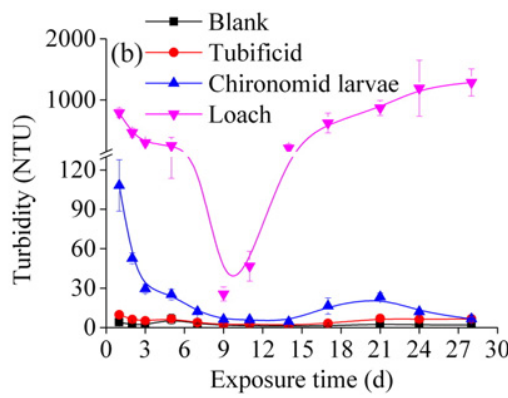

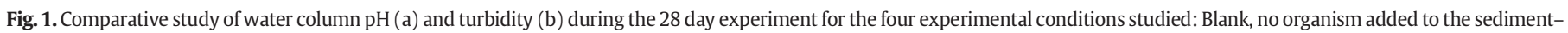
water biotope; Tubificid, presence of Tubificid; Chironomid larvae, presence of Chironomid larvae; Loach, presence of Loach. 

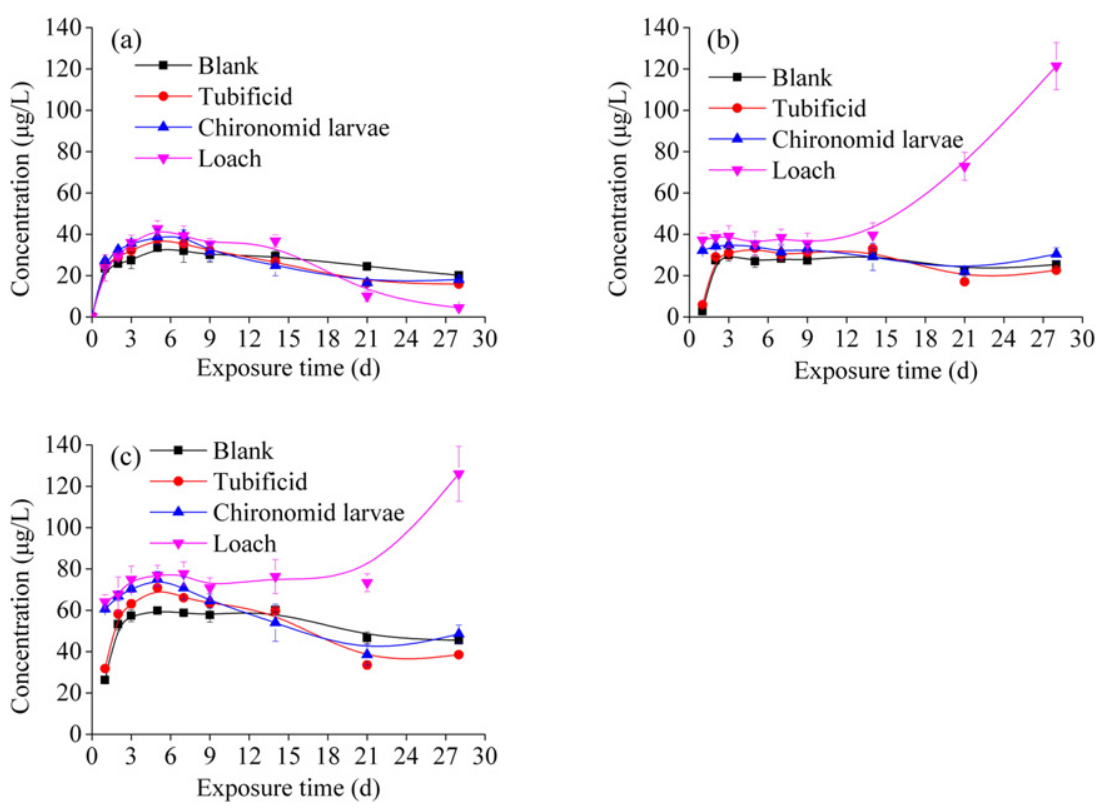

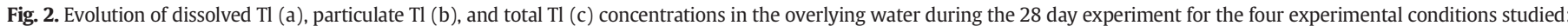
Blank, no organism added to the sediment-water biotope; Tubificid, presence of Tubificid; Chironomid larvae, presence of Chironomid larvae; Loach, presence of Loach.

Iron
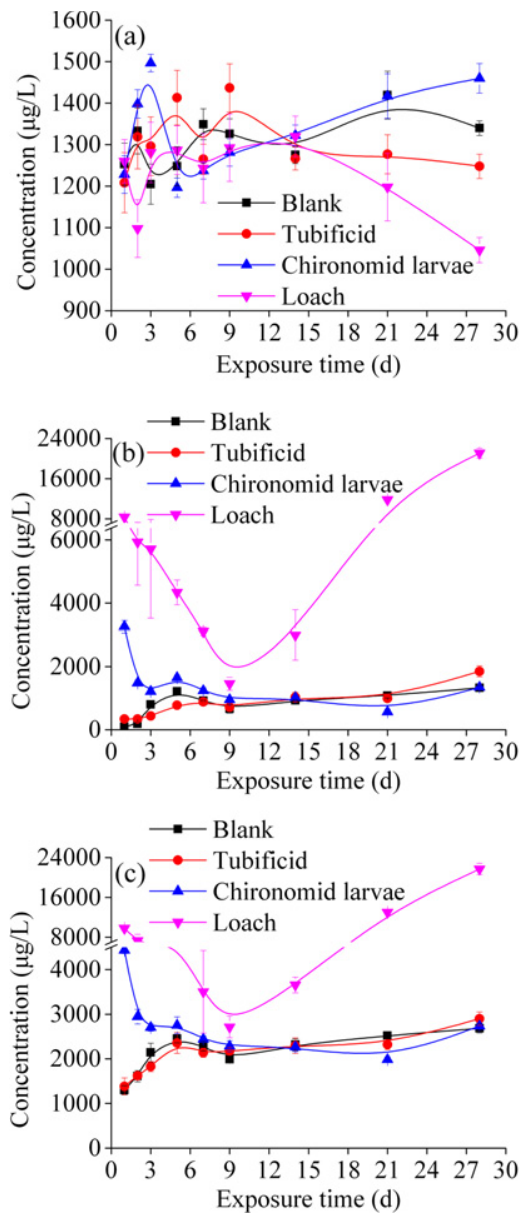

\section{Manganese}
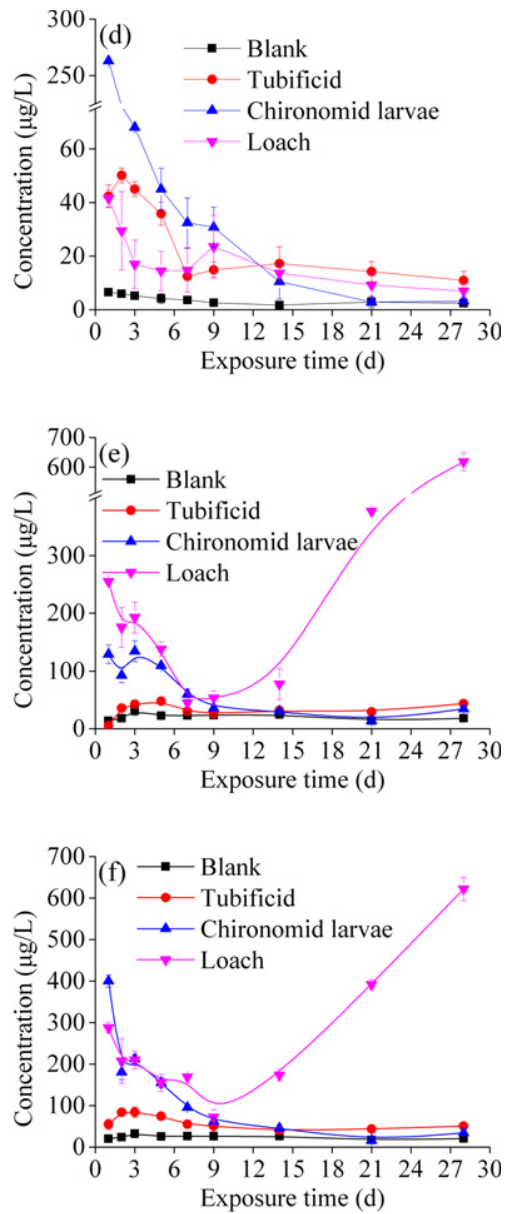

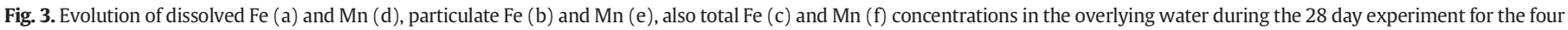

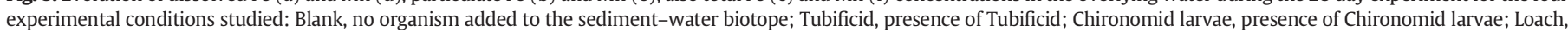
presence of Loach. 
concentration ranges were as follows: blank, $26.9 \pm 2.9-30.7 \pm 2.8 \mu \mathrm{g} / \mathrm{L}$ and Tubificid, $29.0 \pm 1.6-33.3 \pm 0.8 \mu \mathrm{g} / \mathrm{L}$. The total Tl concentration ranges were: blank, 53.2 $\pm 2.9-60.2 \pm 1.0 \mu \mathrm{g} / \mathrm{L}$ and Tubificid, $58.2 \pm$ $2.1-70.9 \pm 1.8 \mu \mathrm{g} / \mathrm{L}$. After 14 days, the total and particulate Tl concentrations of only Loach group increased sharply and reached a peak (28th d, Loach: particulate, $121.4 \pm 11.4 \mu \mathrm{g} / \mathrm{L}$; total, $126.0 \pm 13.3 \mu \mathrm{g} / \mathrm{L})$; the other groups gradually decreased from 14 to 21 days and slowly increased until 28 days, finally the concentration was only slightly lower than the steady state concentration before.

\subsection{Fe and $M n$ in the overlying water}

Dissolved Fe (Fig. 3a) concentrations in the overlying water fluctuated within a certain range during the exposure time. After 28 days, only the concentration of the Chironomid larvae group was higher than the blank group (28th day: blank, $1339.8 \pm 17.5 \mu \mathrm{g} / \mathrm{L}$; Tubificid, $1247.8 \pm 29.4 \mu \mathrm{g} / \mathrm{L}$; Chironomid larvae, $1459.7 \pm 35.6 \mu \mathrm{g} / \mathrm{L}$; Loach, $1045.8 \pm 30.4 \mu \mathrm{g} / \mathrm{L}$ ). The release of dissolved Mn (Fig. 3d) into the overlying water was fast. The maximum values were found on the first day (blank, $6.5 \pm 1.2 \mu \mathrm{g} / \mathrm{L}$; Chironomid larvae, $262.9 \pm 1.6 \mu \mathrm{g} / \mathrm{L}$; Loach, $41.8 \pm 3.3 \mu \mathrm{g} / \mathrm{L}$ ) except the Tubificid group on the second day (Tubificid, $50.1 \pm 2.8 \mu \mathrm{g} / \mathrm{L}$ ). Then the dissolved Mn concentrations in the overlying water began to decline. At the end of the experiment, the concentrations in the biological groups were all higher than the blank group (28th day: blank, $2.4 \pm 0.9 \mu \mathrm{g} / \mathrm{L}$; Tubificid, $10.9 \pm 3.3 \mu \mathrm{g} / \mathrm{L}$; Chironomid larvae, $3.2 \pm 1.3 \mu \mathrm{g} / \mathrm{L}$; Loach, $6.9 \pm 2.7 \mu \mathrm{g} / \mathrm{L}$ ).

Particulate Fe (Fig. 3b) and Mn (Fig. 3e) concentrations as a function of time showed the similar trends with the total Fe and Mn concentrations, respectively. No significant difference was found between the Tubificid and blank groups, which remained at a relatively low value during the whole experiment. In contrast, the particulate Fe (Fig. 3b) and Mn (Fig. 3e) concentrations in the Chironomid larvae and Loach groups were different from that in the Tubificid and blank groups, which rapidly decreased for the first 9 days, then increased sharply from 9 to 28 days. At the end of the experiment, biological groups had higher particulate Fe (28th day: blank, $1327.6 \pm 81.8 \mu \mathrm{g} / \mathrm{L}$; Tubificid, $1850.4 \pm 175.8 \mu \mathrm{g} / \mathrm{L}$; Chironomid larvae, $1343.8 \pm 44.8 \mu \mathrm{g} / \mathrm{L}$; Loach, $21088.3 \pm 985.4 \mu \mathrm{g} / \mathrm{L}$ ) and Mn concentrations (28th day: blank, $18.1 \pm 4.0 \mu \mathrm{g} / \mathrm{L}$; Tubificid, $43.8 \pm 1.7 \mu \mathrm{g} / \mathrm{L}$; Chironomid larvae, $34.5 \pm$ $2.9 \mu \mathrm{g} / \mathrm{L}$; Loach, $618.2 \pm 30.0 \mu \mathrm{g} / \mathrm{L}$ ) than the blank group.

\subsection{Bioaccumulation of $\mathrm{Tl}$ by the three organisms}

The initial background $\mathrm{Tl}$ concentrations in the whole body of the three organisms were $5.1 \times 10^{-2} \mathrm{mg} / \mathrm{kg}$ dw in Tubificid, $0.2 \mathrm{mg} / \mathrm{kg}$

Table 2

Thallium concentrations in bioturbation/bioirrigation and bioaccumulation studies.

\begin{tabular}{|c|c|c|c|c|c|c|c|c|c|}
\hline $\begin{array}{l}\text { Thallium } \\
\text { concentrations }\end{array}$ & $\begin{array}{l}1 \\
\text { day }\end{array}$ & $\begin{array}{l}2 \\
\text { days }\end{array}$ & $\begin{array}{l}3 \\
\text { days }\end{array}$ & $\begin{array}{l}5 \\
\text { days }\end{array}$ & $\begin{array}{l}7 \\
\text { days }\end{array}$ & $\begin{array}{l}9 \\
\text { days }\end{array}$ & $\begin{array}{l}14 \\
\text { days }\end{array}$ & $\begin{array}{l}21 \\
\text { days }\end{array}$ & $\begin{array}{l}28 \\
\text { days }\end{array}$ \\
\hline \multicolumn{10}{|c|}{$\mathrm{Tl}$ in the overlying water $(\mu \mathrm{g} / L)$} \\
\hline \multicolumn{10}{|c|}{ Tubificid } \\
\hline Dissolved Tl & 25.9 & 29.2 & 32.1 & 37.7 & 35.4 & 32.1 & 26.8 & 16.4 & 15.9 \\
\hline Particulate $\mathrm{Tl}$ & 5.9 & 29.0 & 31.0 & 33.3 & 30.0 & 31.2 & 33.0 & 17.0 & 22.6 \\
\hline Total Tl & 31.8 & 58.2 & 63.1 & 70.9 & 66.1 & 63.3 & 59.8 & 33.5 & 38.5 \\
\hline \multicolumn{10}{|l|}{ Chironomid larvae } \\
\hline Dissolved $\mathrm{Tl}$ & 27.3 & 32.5 & 35.6 & 38.7 & 39.3 & 31.5 & 24.8 & 16.5 & 18.1 \\
\hline Particulate $\mathrm{Tl}$ & 32.2 & 34.3 & 34.8 & 34.3 & 31.4 & 33.1 & 29.1 & 22.0 & 30.4 \\
\hline Total Tl & 60.6 & 66.7 & 70.4 & 75.2 & 70.7 & 64.6 & 53.9 & 38.5 & 48.5 \\
\hline \multicolumn{10}{|l|}{ Loach } \\
\hline Dissolved Tl & 23.8 & 29.4 & 36.0 & 42.7 & 39.3 & 35.3 & 36.8 & 10.1 & 4.4 \\
\hline Particulate $\mathrm{Tl}$ & 37.2 & 38.5 & 39.0 & 35.4 & 38.4 & 35.6 & 39.6 & 72.9 & 121.4 \\
\hline Total Tl & 64.1 & 67.8 & 75.0 & 76.9 & 77.8 & 70.8 & 76.4 & 73.4 & 126.0 \\
\hline \multicolumn{10}{|c|}{ Bioaccumulation of $\mathrm{Tl}$ in organisms $(\mathrm{mg} / \mathrm{kg}, \mathrm{dw}$ ) } \\
\hline Tubificid & - & - & - & - & 28.7 & - & 22.1 & 19.2 & 18.5 \\
\hline Chironomid larvae & - & - & - & - & 5.1 & - & 3.9 & 4.2 & 1.3 \\
\hline Loach & - & - & - & - & 1.1 & - & 6.9 & 6.3 & 6.7 \\
\hline
\end{tabular}

dw in Loach and not detected in Chironomid larvae. Both the Tubificid and Chironomid larvae had the peak accumulation on the 7th day (Tubificid, $28.7 \mathrm{mg} / \mathrm{kg} \mathrm{dw}$; Chironomid larvae, $5.1 \mathrm{mg} / \mathrm{kg} \mathrm{dw}$ ) (Table 2). The Loach's highest accumulation was $6.9 \mathrm{mg} / \mathrm{kg}$ dw on the 14th day. Bioaccumulation by Tubificid decreased with time after the peak concentration. There was not much change of bioaccumulation by the Chironomid larvae from 7-21 days; and with the treatment with Loach, bioaccumulation had been comparatively stable for 14 days.

\section{Discussion}

\section{1. $p H$ and turbidity}

Bioturbation can change the physical properties and the biogeochemistry of the sediment (Krantzberg, 1985; Kristensen, 2000). The change of $\mathrm{pH}$ in the overlying water was in relation to the following aspects (Fig. 4): (a) Aeration decreased the carbon dioxide concentration in the overlying water, at the same time, oxygen accelerated the aerobic decomposition of organic matter, producing carbon dioxide. (b) Biological respiration, organism consumed oxygen and resulting in $\mathrm{CO}_{2}$, leading to the decrease of $\mathrm{pH}$ in the overlying water. (c) Also, mixing release nutrients that enhance growth and reproduction of phytoplankton, photosynthesis of phytoplankton consumed $\mathrm{CO}_{2}$ fast, increase the $\mathrm{pH}$. The overlying water turned green during the exposure time. The gradation of the visual color was in the order of Loach $>$ Chironomid larvae $>$ Tubificid $>$ blank. The order was along with the $\mathrm{pH}$ value order. In a highly eutrophic lake, the $\mathrm{pH}$ of the water can rise to more than 9.0 (Wang and Wang, 1993). The $\mathrm{pH}$ change was the result of a combination of these three phenomena that undergo simultaneously. In this study, the most important process of the experiment that affected the $\mathrm{pH}$ must be the photosynthesis of phytoplankton which survived by the bioturbation. Without bioturbation, the $\mathrm{pH}$ of the overlying water increased gradually with time, which was probably due to the photosynthesis of microbial and phytoplankton that tends to increase the $\mathrm{pH}$ levels. Bioturbation obviously enhanced the photosynthesis process of microbial and phytoplankton, which further increased the $\mathrm{pH}$ values, especially for the Loach group. However, some research showed the drop of the $\mathrm{pH}$ in the overlying water with bioturbation, which can be attributed to the oxygenation of the sediment and an increase in the mineralization of detritic organic matter by bacteria, resulting in the production of carbon dioxide, which tends to bring down pH levels (Jiang et al., 2010). Oxidation of anoxic sediments leads to an increase in microbial (thiobacteria) activity and a decrease in sediment $\mathrm{pH}$ (mainly due to the oxidation of sulfide) (Forstner et al., 1989; Petersen et al., 1997; Simpson et al., 1998). Therefore, the $\mathrm{pH}$ change in the overlying water during sediment disturbance is related to the characterization of sediment, which can bring down or increase the $\mathrm{pH}$ values by the microbes (thiobacteria) and phytoplankton activities.

Turbidity increased significantly when the organisms just entered the system because they moved to the interface of sediment and water. Tubificid and Chironomid larvae moved into the deep depths of sediments with the extension of the experiment time, sediment surface recovered as peaceful state and the sediment resuspension in the overlying water decreased. After 15 days, turbidity of the Tubificid and Chironomid larvae groups became larger again. It can be observed clearly that some Tubificid and Chironomid larvae moved to the sediment surface. Turbidity of the Loach group has maintained a high level because of its larger size and always living in the sediment surface with vigorous activity, resulting in continuous sediment resuspension.

\subsection{Thallium in the overlying water}

This study used a monovalent $\mathrm{Tl}$ which has properties similar to the alkali metal which is very lively in the environment. Therefore, the transfer of dissolved $\mathrm{Tl}$ from sediments in water was expected to be 
Aeration

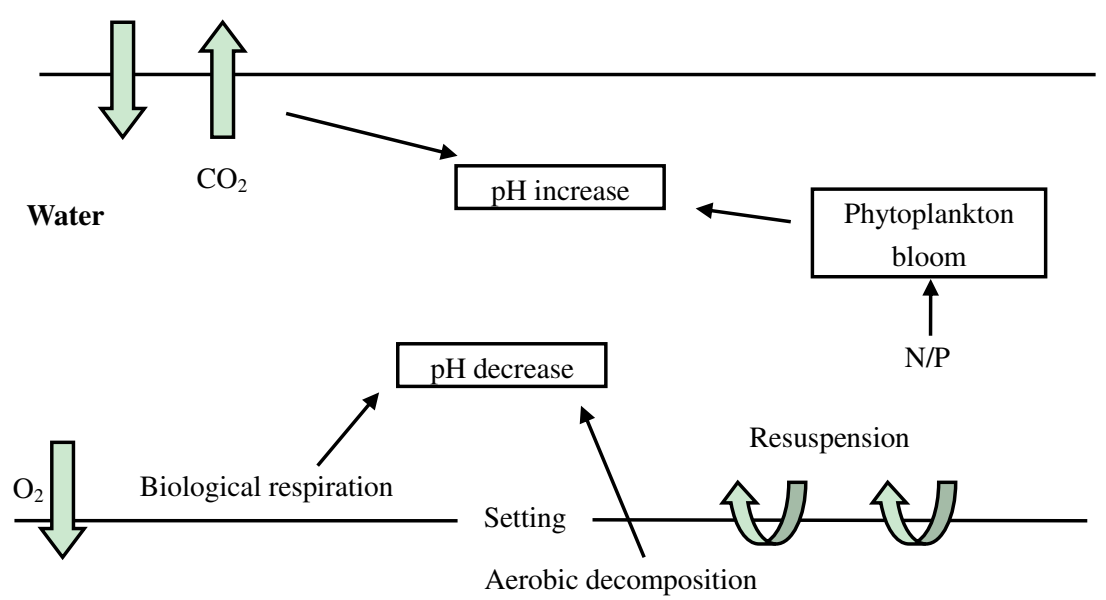

Sediment

Pore water

Fig. 4. The impact factors of $\mathrm{pH}$ in the overlying water by bioturbation/bioirrigation.

easy, and the results matched this expectation. Thallium adsorption to riverine sediment is a rapid process only $12 \mathrm{~h}$ (Wang et al., 2013) or $16 \mathrm{~h}$ (Turner et al., 2010) equilibration period. In this study, the interrupt time of each sampling was at least $24 \mathrm{~h}$ to ensure that the Tl was in a state of dynamic balance in the interface of sediment and overlying water. According to the literature, the resuspension of sediment results in variable desorption rates of metals absorbed to sulfides (Caille et al., 2003). Metals coprecipitated with or absorbed to FeS and MnS are rapidly oxidized following sediment resuspension, due to their relative solubility in oxic conditions (Allen et al., 1993; Caetano et al., 2003). Also, organic matter has a relevant role since its structural features allow its interaction with substances like metals, modifying its mobility and availability to organisms (Cardoso et al., 2008). Thallium may also exist in the sediments precipitated as sulfides or associated with $\mathrm{Fe}$ and Mn sulfides. Bioturbation/bioirrigation by Tubificid, Chironomid larvae and Loach resulting in sediment resuspension and substance exchange between overlying water and pore water leads to the release of $\mathrm{Tl}$ into the water column, as a consequence of the change of sulfides
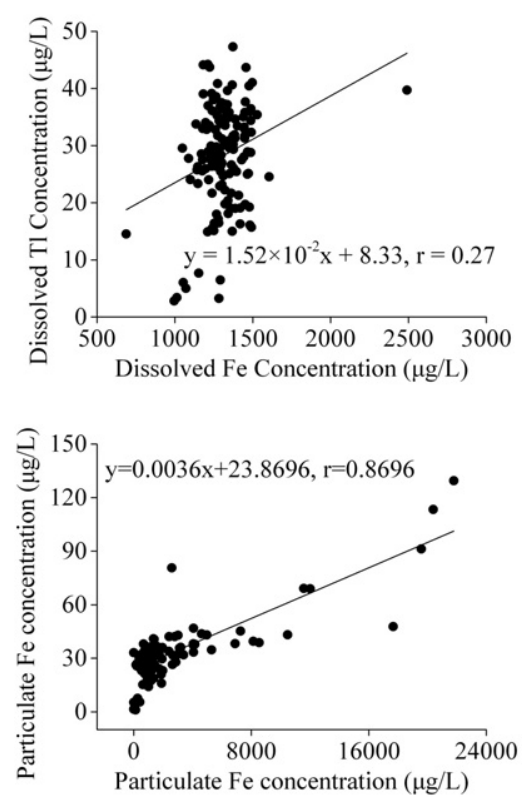

and organic matter. Therefore, during the first few days, the dissolved $\mathrm{Tl}$ in bioturbation groups was significantly increased, higher than the no bioturbation group. However, the dissolved $\mathrm{Tl}$ in bioturbation groups was all lower than that in the blank group after 28 days, which was probably due to the formation of Fe and Mn hydrous oxides as a consequence of alkaline $\mathrm{pH}$ values that tends to sorb or coprecipitate heavy metals like Tl under alkaline conditions. The concentration of particulate Fe and Mn confirmed this hypothesis. The particulate Fe and Mn had significant correlation with $\mathrm{Tl}$ (Fig. $5, \mathrm{r}_{\mathrm{Fe}-\mathrm{Tl}}=0.87$. $\mathrm{p}<0.01 ; \mathrm{r}_{\mathrm{Mn}-\mathrm{Tl}}=$ $0.75, \mathrm{p}<0.01)$.

Additionally, planktonic bacteria may be responsible for oxidizing the thermodynamically stable $\mathrm{Tl}(\mathrm{I})$ to the more abundant $\mathrm{Tl}(\mathrm{III})$ (Twining et al., 2003). Once produced, however, Tl(III) may be stabilized by complexation to both inorganic and organic ligands, although it is a strong oxidant $(1.28 \mathrm{~V})$ that could readily be reduced by coupling with chemical species such as sulfide or organic matter (Lin and Nriagu, 1998). This may be another important reason for the decrease of dissolved $\mathrm{Tl}$ concentration in the Loach group, which was found to
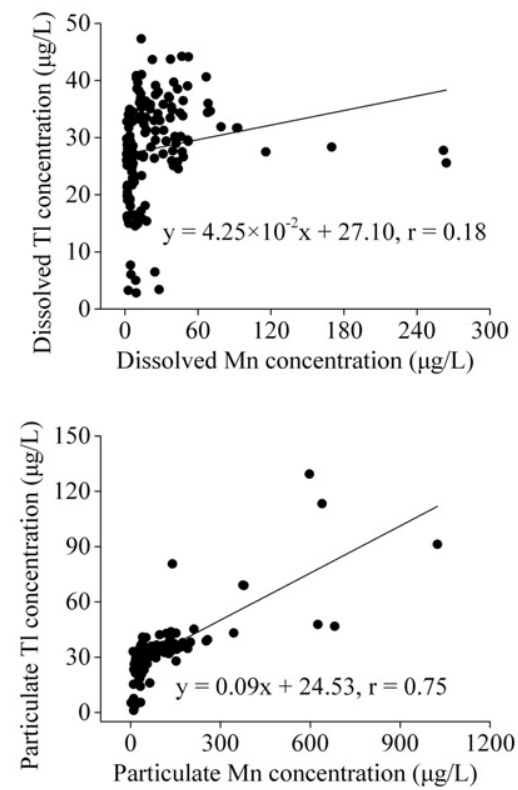
remarkably enhance the photosynthesis process of microbial and phytoplankton. On the other hand, in the presence of Tubificid and Chironomid larvae, concentrations of different forms of $\mathrm{Tl}$ showed no significant difference from that of the blank group after 28 days, indicating that the main process of dissolved $\mathrm{Tl}$ release was the simple diffusion of the sediment pore water to the overlying water. The turbidity results of the Tubificid and Chironomid larvae groups agreed with this, which was a little higher than that of the blank group.

In the presence of Loach, most Tl was in the particulate forms with relatively high values, which agreed with the turbidity concentrations. Bioturbation led to a resuspension of sediment particles, thereby increased the concentration of particulate Tl. After 14 days, the total and particulate $\mathrm{Tl}$ concentrations in microcosms with Loach were completely different from the Tubificid and Chironomid larvae groups, which increased significantly at the end of the experiments. The correlation between turbidity and $\mathrm{Tl}$ concentrations showed its contribution to the different forms of metals in the overlying water. Significant correlations were found between particulate $\mathrm{Tl}$ and turbidity (Fig. 6) $\left(\mathrm{r}_{\mathrm{T}-\mathrm{Tl}}=0.74, \mathrm{p}<0.01\right)$. Similar results were found between the total Tl and the turbidity $\left(\mathrm{r}^{\prime} \mathrm{T}-\mathrm{Tl}=0.50, \mathrm{p}<0.01\right)$. With Tubificid and Chironomid larvae, dissolved $\mathrm{Tl}$ concentration had similar values with the particulate $\mathrm{Tl}$ concentration in the overlying water, which was significantly different from that of Loach.

\subsection{Bioaccumulation of $\mathrm{Tl}$ in the organisms}

Throughout the experiment, three organisms showed different bioaccumulation laws with Tl. Among the three organisms, the Tubificid had the best enrichment capability to $\mathrm{Tl}$, followed by Loach, and then Chironomid larvae (Fig. 7). Bioaccumulation of heavy metals by organisms was affected by its own metabolism, feeding, environmental concentration, exposure time and its forms and so on. Ciutat and Boudou (2003) found that $78 \%$ of particles ingested by Tubificid were below $63 \mu \mathrm{m}$ in diameters, $50 \%$ of particles being below $25 \mu \mathrm{m}$. So the Tubificid ingest the smallest particles of the sediment which are likely to have the highest $\mathrm{Tl}$ content. According to the literature, thallium was lethal to aquatic insects and invertebrates at $2-4 \mathrm{mg} / \mathrm{L}$ (Zitko et al., 1975). The available data for $\mathrm{Tl}$ indicated that acute and chronic toxicity to freshwater aquatic life occurs at concentrations as low as 1400 and $40 \mathrm{ppb}$, respectively, and would occur at lower concentrations among species that were more sensitive than those tested (U.S.EPA,
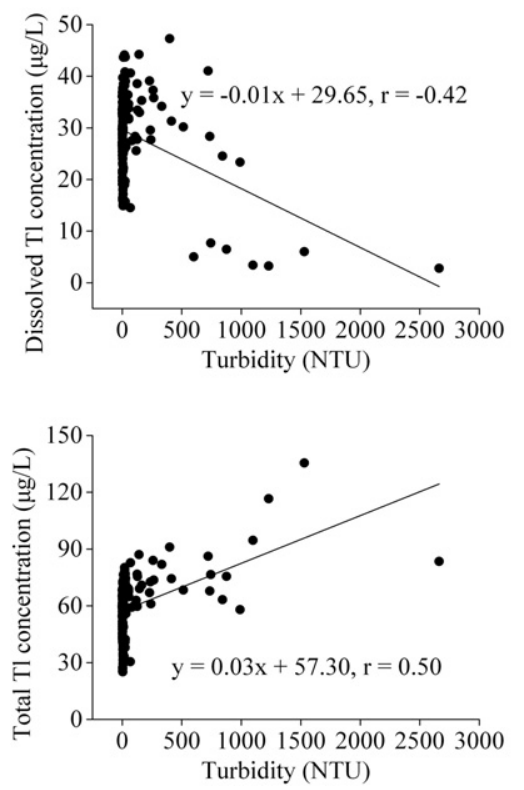

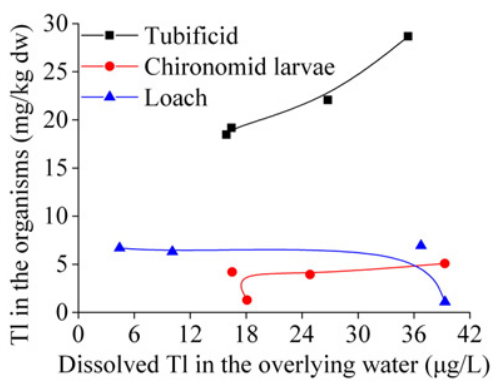

Fig. 7. The bioaccumulation by the three organisms along with the dissolved Tl concentrations in the overlying water at different exposure time ( 7 days, 14 days, 21 days and 28 days).

1980). The acute ( $48 \mathrm{~h}$ ) lethal concentration where $50 \%$ of the organisms do not survive $\left(\mathrm{LC}_{50}\right)$ values of $\mathrm{Tl}$ for 4 th instar Chironomus riparius larvae was $723 \mu \mathrm{mol} / \mathrm{L}$ (Belowitz et al., 2014). The dissolved Tl concentrations of the overlying water in this study were much lower than that.

Consequently, the process of the bioturbation/bioirrigation with different organism types should be taken into account when evaluating the effectiveness of amendments or in the risk assessment of contaminated sediments. However, the results found in the present study may not always apply to the risk evaluation of contaminated sediments under field conditions because the contaminated sediment was stirred by mechanical mixing to homogenize the $\mathrm{Tl}$ distribution in the sediment, which destroyed the sediment profile in the natural environment. For instance, in the field factors such as the surface sediment characteristics and degree of sediment consolidation may differ from our laboratory setting.

\section{Conclusion}

This study demonstrated that bioturbation by different organisms of artificially contaminated sediments with $\mathrm{Tl}$ increased the $\mathrm{pH}$ values in the overlying water for all the biological groups, especially for the Loach group, due to the photosynthesis process of microbial and phytoplankton. Additionally, during the first 9 days, bioturbation enhanced release of $\mathrm{Tl}$ into the water column. However, after 28 days, the bioturbation process seemed to suppress the release of dissolved $\mathrm{Tl}$ from the

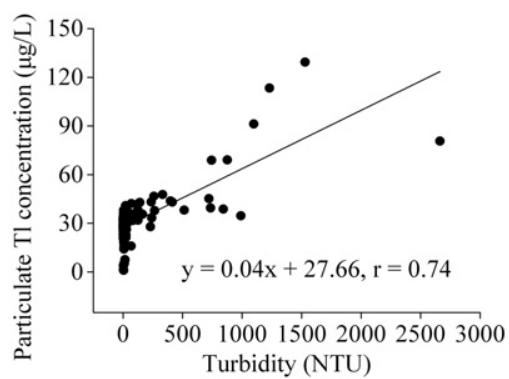


sediment to the water column. The formation of Fe and Mn hydrous oxides as a consequence of alkaline $\mathrm{pH}$ value which tends to sorb or coprecipitate heavy metals may be the main reason for the reduced dissolved $\mathrm{Tl}$ concentration of biological groups compared with the blank group after 28 days. In addition, planktonic bacteria may be responsible for oxidizing the $\mathrm{Tl}(\mathrm{I})$ to the $\mathrm{Tl}(\mathrm{III})$ with the predominant form being $\mathrm{Tl}(\mathrm{OH})_{3}$, which need further investigation. The turbidity, indicating the different activities of the organisms, had significant correlation with particulate and total $\mathrm{Tl}$, showing its contribution to the particulate and total heavy metals.

\section{Acknowledgments}

This study was sponsored by the National Natural Scientific Foundation of China $(41201498,21107125,51290282)$, the National High Technology Research and Development Program of China (2013AA065602), and the National Water Pollution Control and Treatment Science and Technology Major Project (2015ZX07205-003).

\section{References}

Agency, X.N., 2010. Production Suspended at S China Smeltery as Thallium Contamination Detected. In: Xiang, Z. (Ed.), .

Allen, H.E., Fu, G.M., Deng, B.L., 1993. Analysis of acid-volatile sulfide (AVS) and simultaneously extracted metals (SEM) for the estimation of potential toxicity in aquatic sediments. Environ. Toxicol. Chem. 12, 1441-1453.

Banta, G.T., Andersen, O., 2003. Bioturbation and the fate of sediment pollutants - experimental case studies of selected infauna species. Vie Et Milieu-Life Environ. 53, 233-248.

Belowitz, R., Leonard, E.M., O'Donnell, M.J., 2014. Effects of exposure to high concentrations of waterborne $\mathrm{Tl}$ on $\mathrm{K}$ and $\mathrm{Tl}$ concentrations in Chironomus riparius larvae. Comp. Biochem. Physiol. C Toxicol. Pharmacol. 166, 59-64.

Caetano, M., Madureira, M.J., Vale, C., 2003. Metal remobilisation during resuspension of anoxic contaminated sediment: short-term laboratory study. Water Air Soil Pollut. $143,23-40$.

Caille, N., Tiffreau, C., Leyval, C., Morel, J.L., 2003. Solubility of metals in an anoxic sediment during prolonged aeration. Sci. Total Environ. 301, 239-250.

Cardoso, P.G., Lillebo, A.I., Lopes, C.B., Pereira, E., Duarte, A.C., Pardal, M.A., 2008. Influence of bioturbation by Hediste diversicolor on mercury fluxes from estuarine sediments: a mesocosms laboratory experiment. Mar. Pollut. Bull. 56, 325-334.

Ciutat, A., Boudou, A., 2003. Bioturbation effects on cadmium and zinc transfers from a contaminated sediment and on metal bioavailability to benthic bivalves. Environ. Toxicol. Chem. 22, 1574-1581.

Dafoe, L.T., Rygh, A.L., Yang, B., Gingras, M.K., Pemberton, S.G., 2011. A new technique for assessing tubificid burrowing activities, and recognition of biogenic grading formed by these oligochaetes. Palaios 26, 66-80.

D'Souza, S.F., Sar, P., Kazy, S.K., Kubal, B.S., 2006. Uranium sorption by Pseudomonas biomass immobilized in radiation polymerized polyacrylamide bio-beads. J. Environ. Sci. Health. Part A Toxic/Hazard. Subst. Environ. Eng. 41, 487-500.

Duan, L., Song, J., Li, X., Yuan, H., Li, N., Xu, Y., 2012. Thallium concentrations and sources in the surface sediments of Bohai Bay. Mar. Environ. Res. 73, 25-31.

Forstner, U., Ahlf, W., Calmano, W., 1989. Studies on the transfer of heavy-metals between sedimentary phases with a multi-chamber device - combined effects of salinity and redox variation. Mar. Chem. 28, 145-158.

Gang, S.U.N., Lianxi, S., Senga, Y., 2006. Advance in bioturbation effect in benthic-pelagic interface. Ecol. Environ. 15, 1106-1110.

Granberg, M.E., Gunnarsson, J.S., Hedman, J.E., Rosenberg, R., Jonsson, P., 2008. Bioturbation-driven release of organic contaminants from baltic sea sediments mediated by the invading polychaete Marenzelleria neglecta. Environ. Sci. Technol. 42, 1058-1065.

Hunting, E.R., Mulder, C., Kraak, M.H.S., Breure, A.M., Admiraal, W., 2013. Effects of copper on invertebrate-sediment interactions. Environ. Pollut. 180, 131-135.

Jiang, P.-H., Ji, L., Xiao, W.-J., Huang, D.-Z., Liu, Y.-B., Song, C.-L., et al., 2010. Bioturbation of two chironomid species on nutrient exchange at sediment-water interface in a Chinese shallow eutrophic lake. Fresenius Environ. Bull. 19, 902-910.

Josefsson, S., Leonardsson, K., Gunnarsson, J.S., Wiberg, K., 2010. Bioturbation-driven release of buried PCBs and PBDEs from different depths in contaminated sediments. Environ. Sci. Technol. 44, 7456-7464.

Krantzberg, G., 1985. The influence of bioturbation on physical, chemical and biological parameters in aquatic environments - a review. Environ. Pollut. A Ecol. Biol. 39, 99-122.
Kristensen, E., 2000. Organic matter diagenesis at the oxic/anoxic interface in coastal marine sediments, with emphasis on the role of burrowing animals. Hydrobiologia 426, $1-24$

Lagauzere, S., Pischedda, L., Cuny, P., Gilbert, F., Stora, G., Bonzom, J.M., 2009. Influence of Chironomus riparius (Diptera, Chironomidae) and Tubifex tubifex (Annelida, Oligochaeta) on oxygen uptake by sediments. Consequences of uranium contamination. Environ. Pollut. 157, 1234-1242.

Larsson, P., 1985. Contaminated sediments of lakes and oceans act as sources of chlorinated hydrocarbons for release to water and atmosphere. Nature 317, 347-349.

Lin, Z., 1997. Mobilization and retention of heavy metals in mill-tailings from Garpenberg sulfide mines, Sweden. Sci. Total Environ. 198, 13-31.

Lin, T.S., Nriagu, J., 1998. Thallium in the Environment. John Wiley \& Sons Inc., New York

Lin, T.S., Nriagu, J., Wang, K.Q., 2001. Thallium concentration in lake trout from Lake Michigan. Bull. Environ. Contam. Toxicol. 67, 921-925.

Lis, J., Pasieczna, A., Karbowska, B., Zembrzuski, W., Lukaszewski, Z., 2003. Thallium in soils and stream sediments of a $\mathrm{Zn}-\mathrm{Pb}$ mining and smelting area. Environ. Sci. Technol. 37, 4569-4572.

Liu, J., Lippold, H., Wang, J., Lippmann-Pipke, J., Chen, Y., 2011. Sorption of thallium(I) onto geological materials: influence of $\mathrm{pH}$ and humic matter. Chemosphere 82, 866-871.

Mermillod-Blondin, F., Nogaro, G., Vallier, F., Gibert, J., 2008. Laboratory study highlights the key influences of stormwater sediment thickness and bioturbation by tubificid worms on dynamics of nutrients and pollutants in stormwater retention systems. Chemosphere 72, 213-223.

Michaud, E., Desrosiers, G., Mermillod-Blondin, F., Sundby, B., Stora, G., 2006. The functional group approach to bioturbation: II. The effects of the Macoma balthica community on fluxes of nutrients and dissolved organic carbon across the sediment-water interface. J. Exp. Mar. Biol. Ecol. 337, 178-189.

Mulkey, J.P., Oehme, F.W., 1993. A review of thallium toxicity. Vet. Hum. Toxicol. 35 445-453.

Nogaro, G., Burgin, A.J., Schoepfer, V.A., Konkler, M.J., Bowman, K.L., Hammerschmidt, C.R. 2013. Aluminum sulfate (alum) application interactions with coupled metal and nutrient cycling in a hypereutrophic lake ecosystem. Environ. Pollut. 176, 267-274.

Peter, A.L.J., Viraraghavan, T., 2005. Thallium: a review of public health and environmental concerns. Environ. Int. 31, 493-501.

Petersen, W., Willer, E., Willamowski, C., 1997. Remobilization of trace elements from polluted anoxic sediments after resuspension in oxic water. Water Air Soil Pollut. 99, 515-522.

Qi, W.-Q., Cao, J.-S., Chen, Y.-L., 1992. Research of indium (In) and thallium (Tl) environmental background value of soil. Chin. J. Soil Sci. 23, 31-33.

Rhoads, D.C., 1974. Organism-sediment relations on the muddy sea floor. Mar. Biol. Ann. Rev. 12, 263-300.

Schaller, J., 2014. Bioturbation/bioirrigation by Chironomus plumosus as main factor controlling elemental remobilization from aquatic sediments? Chemosphere 107, 336-343.

Simpson, S.L., Apte, S.C., Batley, G.E., 1998. Effect of short term resuspension events on trace metal speciation in polluted anoxic sediments. Environ. Sci. Technol. 32, 620-625.

Smith, I.C., Carson, B.L., 1977. Trace Metals in the Environment, Volume 1-Thallium. Ann Arbor Science Publishers Inc., Michigan.

Sridhar, K.R., Baerlocher, F., Wennrich, R., Krauss, G.--., Krauss, G., 2008. Fungal biomass and diversity in sediments and on leaf litter in heavy metal contaminated waters of Central Germany. Fundam. Appl. Limnol. 171, 63-74.

Tengberg, A., Almroth, E., Hall, P., 2003. Resuspension and its effects on organic carbon recycling and nutrient exchange in coastal sediments: in situ measurements using new experimental technology. J. Exp. Mar. Biol. Ecol. 285, 119-142.

Thibodeaux, L.J., Bierman, V.J., 2003. The bioturbation-driven chemical release process. Environ. Sci. Technol. 37, 252A-258A.

Turner, A., Cabon, A., Glegg, G.A., Fisher, A.S., 2010. Sediment-water interactions of thallium under simulated estuarine conditions. Geochim. Cosmochim. Acta 74, 6779-6787.

Twining, B.S., Twiss, M.R., Fisher, N.S., 2003. Oxidation of thallium by freshwater plankton communities. Environ. Sci. Technol. 37, 2720-2726.

U.S.EPA, 1980. NTIS. Ambient Water Quality Criteria for Thallium. EPA 440/5-80-074. U.S Department of Commerce, Springfield, VA.

Wang, G.-z., Wang, P.-x., 1993. Environmental Information of Lacustrine Carbonate. Ocean Press, Beijing, pp. 78-95.

Wang, X., Yang, X.-f., Wang, D.-s., Xia, H., 2013. Adsorption and desorption behavior of $\mathrm{Tl}(\mathrm{I})$ in river sediments. Acta Sci. Circumst. 33, 535-543.

Widdows, J., Brinsley, M.D., Bowley, N., Barrett, C., 1998. A benthic annular flume for in situ measurement of suspension feeding/biodeposition rates and erosion potential of intertidal cohesive sediments. Estuar. Coast. Shelf Sci. 46, 27-38.

Zhao, Y., Yan, M., 1994. Geochemistry of Sediments of the China Shelf Sea. Science Press, Beijing.

Zitko, V., Carson, W.V., Carson, W.G., 1975. Thallium - occurrence in environment and toxicity to fish. Bull. Environ. Contam. Toxicol. 13, 23-30. 